\title{
ansa-Metallocene derivatives
}

\section{$\mathrm{XV} *$. Reversible coordination of a second $\mathrm{CO}$ ligand to $\left(\mathrm{C}_{5} \mathrm{H}_{5}\right)_{2} \mathrm{Cr}(\mathrm{CO})$ and its tetramethylethanediyl-bridged analogue. Evidence for an electron-transfer catalysed ring- slippage reaction. IR studies at elevated gas pressure. II **}

\author{
Edith U. van Raaij and Hans-Herbert Brintzinger *** \\ Fakultät für Chemie, Universität Konstanz, 7750 Konstanz (F.R.G.)
}

\begin{abstract}
IR spectral data reveal that the 18 -electron species $\left(\mathrm{C}_{5} \mathrm{H}_{5}\right)_{2} \mathrm{Cr}(\mathrm{CO})$ is reversibly transformed, at elevated $\mathrm{CO}$ pressures into a dicarbonyl complex, $\left(\mathrm{C}_{5} \mathrm{H}_{5}\right)_{2} \mathrm{Cr}(\mathrm{CO})_{2}$. Close coincidence of the $\nu(\mathrm{CO})$ absorption bands of this dicarbonyl with those of $\left(\eta^{3}-\mathrm{C}_{5} \mathrm{H}_{5}\right)\left(\eta^{5}-\mathrm{C}_{5} \mathrm{H}_{5}\right) \mathrm{W}(\mathrm{CO})_{2}$ and of $\left(\eta^{3}-\mathrm{C}_{5} \mathrm{H}_{7}\right)\left(\eta^{5}-\mathrm{C}_{5} \mathrm{H}_{5}\right) \mathrm{Cr}(\mathrm{CO})_{2}$ indicates that it contains an $\eta^{3}$-bound ring ligand. Equilibrium and kinetic data have been obtained for this $\mathrm{CO}$-induced ring-slippage reaction and for an analogous reaction involving the tetramethylethanediyl-bridged ansa-chromocene carbonyl complex $\left(\mathrm{CH}_{3}\right)_{4} \mathrm{C}_{2}-$ $\left(\mathrm{C}_{5} \mathrm{H}_{4}\right)_{2} \mathrm{Cr}(\mathrm{CO})$. The $\mathrm{CO}$-induced transformation of this complex to $\left(\mathrm{CH}_{3}\right)_{4} \mathrm{C}_{2}\left(\eta^{3}-\right.$ $\left.\mathrm{C}_{5} \mathrm{H}_{4}\right)\left(\eta^{5}-\mathrm{C}_{5} \mathrm{H}_{4}\right) \mathrm{Cr}(\mathrm{CO})_{2}$ is greatly accelerated by small amounts of oxidants, i.e. by the formation of the cationic carbonyl complex $\left(\mathrm{CH}_{3}\right)_{4} \mathrm{C}_{2}\left(\mathrm{C}_{5} \mathrm{H}_{4}\right)_{2} \mathrm{Cr}(\mathrm{CO})^{+}$, which appears to facilitate the $\mathrm{CO}$-induced ring slippage by electron-transfer catalysis.
\end{abstract}

\section{Introduction}

Haptotropic rearrangements of organometallic compounds, especially "ring slippage" reactions of sandwich and half-sandwich complexes attrack considerable current interest. While $\eta^{5} \rightarrow \eta^{1}$ rearrangement reactions of cyclopentadienyl ligands and $\eta^{5} \rightarrow \eta^{1}$, as well as $\eta^{5} \rightarrow \eta^{3}$ rearrangements of indenyl ligands, have recently

* For Part XIV in this series see ref. 1.

** For Part I in this series see ref. 2.

*** To whom correspondence should be addressed. URN: http://nbn-resolving.de/urn:nbn:de:bsz:352-239801 
been observed in several instances, $\eta^{3}$-coordination of cyclopentadienyl ligands, postulated to occur in products and intermediates of $\mathrm{C}_{5} \mathrm{H}_{5}$-ring slippage reactions *, has been structurally confirmed only for the tungstenocene dicarbonyl complex $\left(\eta^{3}-\mathrm{C}_{5} \mathrm{H}_{5}\right)\left(\eta^{5}-\mathrm{C}_{5} \mathrm{H}_{5}\right) \mathrm{W}(\mathrm{CO})_{2}[4,5]$.

Using an IR cell suitable for studies under elevated gas pressures [2], we have now observed reversible formation of related dicarbonyl complexes from the chromocene carbonyl complex $\left(\mathrm{C}_{5} \mathrm{H}_{5}\right)_{2} \mathrm{Cr}(\mathrm{CO})$ [4] and from its ring-bridged ansa-analogue $\left(\mathrm{CH}_{3}\right)_{4} \mathrm{C}_{2}\left(\mathrm{C}_{5} \mathrm{H}_{4}\right)_{2} \mathrm{Cr}(\mathrm{CO})[6]$.

\section{Results and discussion}

Reaction of $\left(\mathrm{C}_{5} \mathrm{H}_{5}\right)_{2} \mathrm{Cr}(\mathrm{CO})$ with an excess of $\mathrm{CO}$

Exposure of toluene solutions of $\left(\mathrm{C}_{5} \mathrm{H}_{5}\right)_{2} \mathrm{Cr}$ to $\mathrm{CO}$ gas at ambient pressure leads to the reversible formation of the monocarbonyl complex $\left(\mathrm{C}_{5} \mathrm{H}_{5}\right)_{2} \mathrm{Cr}(\mathrm{CO})$; this conversion is practically complete at $1 \mathrm{~atm}$ of $\mathrm{CO}$ and temperatures below $0^{\circ} \mathrm{C}$ [4]. Thus the intensity of the monocarbonyl band at $1900 \mathrm{~cm}^{-1}$ is essentially unchanged in the $\mathrm{CO}$ pressure range 1-10 bar. However, when these solutions are subjected to $\mathrm{CO}$ pressure in the range $20-150$ bar, there is, in the course of several hours, a diminuation of this monocarbonyl band, together with the concurrent appearance of two new IR bands at 1940 and $1875 \mathrm{~cm}^{-1}$ (Fig. 1). These changes are especially pronounced at temperatures below $0^{\circ} \mathrm{C}$; at $-30^{\circ} \mathrm{C}$ under 150 bar of $\mathrm{CO}$, the monocarbonyl band at $1900 \mathrm{~cm}^{-1}$ is reduced to a small shoulder next to the strong $\nu(\mathrm{CO})$ band at $1875 \mathrm{~cm}^{-1}$. These spectral changes, which are completely reversible

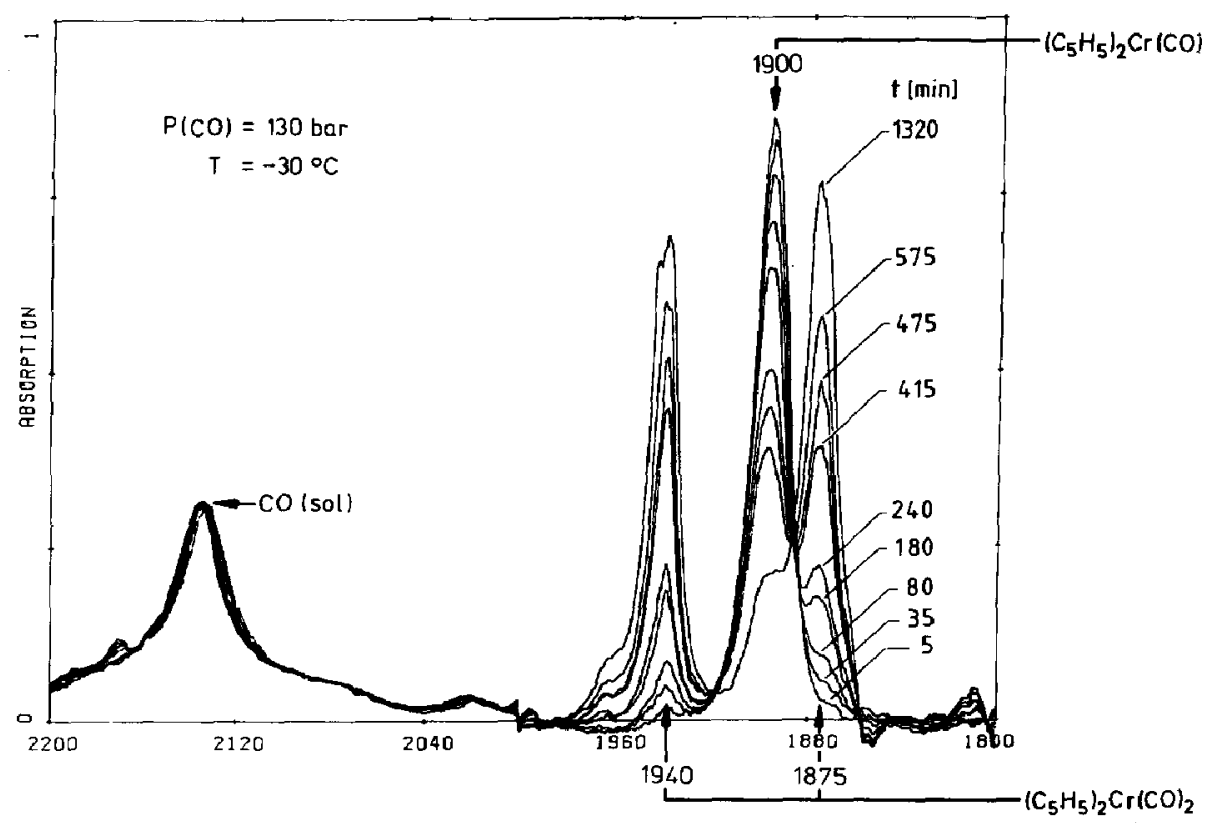

Fig. 1. Variation with time of the IR spectra of carbonyl complexes formed in a $0.05 M$ solution of $\left(\mathrm{C}_{5} \mathrm{H}_{5}\right)_{2} \mathrm{Cr}$ in toluene at $-30^{\circ} \mathrm{C}$ under 130 bar of $\mathrm{CO}$, after subtraction of solvent spectrum.

* See e.g. ref. 3 and further references quoted there. 
upon reduction of the $\mathrm{CO}$ pressure ${ }^{*}$, indicate the formation of a chromocene dicarbonyl complex $\left(\mathrm{C}_{5} \mathrm{H}_{5}\right)_{2} \mathrm{Cr}(\mathrm{CO})_{2}$ under these conditions.

We suggest that the chromocene dicarbonyl complex formed at elevated $\mathrm{CO}$ pressures is a ring-slipped species $\left(\eta^{3}-\mathrm{C}_{5} \mathrm{H}_{5}\right)\left(\eta^{5}-\mathrm{C}_{5} \mathrm{H}_{5}\right) \mathrm{Cr}(\mathrm{CO})_{2}$ rather than a 20electron species with two $\eta^{5}$-bound ring ligands: its $\nu(\mathrm{CO})$ bands at 1940 and 1875 $\mathrm{cm}^{-1}$ are closely coincident with those of its tungsten homologue $\left(\eta^{3}-\mathrm{C}_{5} \mathrm{H}_{5}\right)\left(\eta^{5}-\right.$ $\left.\mathrm{C}_{5} \mathrm{H}_{5}\right) \mathrm{W}(\mathrm{CO})_{2}$ [4] (1945 and $1860 \mathrm{~cm}^{-1}$ in toluene), as well as with those of the necessarily $\eta^{3}$-bound cyclopentenyl species $\left(\eta^{3}-\mathrm{C}_{5} \mathrm{H}_{7}\right)\left(\eta^{5}-\mathrm{C}_{5} \mathrm{H}_{5}\right) \mathrm{Cr}(\mathrm{CO})_{2} * *[8,9]$ (1942 and $1880 \mathrm{~cm}^{-1}$ in isooctane).

Since only 3 electron pairs (i.e. two $\mathrm{CO}$ lone pairs and one $d^{2}$ pair) of an $\left(\eta^{5}-\mathrm{C}_{5} \mathrm{H}_{5}\right)_{2} \mathrm{M}(\mathrm{CO})_{2}$ complex with $\mathrm{M}=\mathrm{Cr}$, Mo or $\mathrm{W}$ can be accommodated (in $1 a_{1}$, $b_{1}$ and $2 a_{1}$ orbitals) in the $\mathrm{M}(\mathrm{CO})_{2}$ plane [10], its remaining two $d$ electrons would have to occupy the orbital $b_{2}$, which lies orthogonal to this plane and is antibonding with respect to the metal-ring interaction. This repulsion is apparently relieved by distortion to the asymmetric $\eta^{3}-\mathrm{C}_{5} \mathrm{H}_{5}$ geometry, probably via second-order Jahn-Teller interactions with close-lying, empty $\pi^{\star}$ orbitals.

The intensity ratio $I_{\text {sym }} / I_{\text {asym }}=1.3$, observed for the symmetric and asymmetric $\nu(\mathrm{CO})$ bands of $\left(\eta^{3}-\mathrm{C}_{5} \mathrm{H}_{5}\right)\left(\eta^{5}-\mathrm{C}_{5} \mathrm{H}_{5}\right) \mathrm{W}(\mathrm{CO})_{2}$ [4], indicates an $\mathrm{OC}-\mathrm{W}-\mathrm{CO}$ angle of $82^{\circ}[11]$ in acceptable agreement with the crystallographically determined value of $75-77^{\circ}$ [5]. For $\left(\mathrm{C}_{5} \mathrm{H}_{5}\right)_{2} \mathrm{Cr}(\mathrm{CO})_{2}$ we oberserve an intensity ratio $I_{\text {sym }} / I_{\text {asym }}$ of 1.0 which indicates a somewhat larger $\mathrm{OC}-\mathrm{Cr}-\mathrm{CO}$ angle of ca. $90^{\circ}$. Similar $\mathrm{OC}-\mathrm{M}-\mathrm{CO}$ angles of 85 to $90^{\circ}$ were crystallographically determined for $\left(\mathrm{C}_{5} \mathrm{H}_{5}\right)_{2} \mathrm{Ti}(\mathrm{CO})_{2}$, $\left(\mathrm{C}_{5} \mathrm{H}_{5}\right)_{2} \mathrm{Zr}(\mathrm{CO})_{2},\left(\mathrm{C}_{5} \mathrm{H}_{5}\right)_{2} \mathrm{Hf}(\mathrm{CO})_{2}$ and $\left(\mathrm{C}_{5} \mathrm{H}_{5}\right)_{2} \mathrm{~V}(\mathrm{CO})_{2}^{+}$[12-14], all of which accommodate one $d^{2}$ pair in their respective $\mathrm{M}(\mathrm{CO})_{2}$ plane.

The dependence of the relative intensities of these mono- and di-carbonyl $\nu(\mathrm{CO})$ bands on the $\mathrm{CO}$ pressure and, hence, on the concentration of dissolved (toluene) $\mathrm{CO} * * *$, is as expected for the equilibrium reaction 1 .

$\left(\mathrm{C}_{5} \mathrm{H}_{5}\right)_{2} \mathrm{Cr}(\mathrm{CO})_{\text {tol }}+\mathrm{CO}_{\text {tol }} \rightleftharpoons\left(\mathrm{C}_{5} \mathrm{H}_{5}\right)_{2} \mathrm{Cr}(\mathrm{CO})_{2 \text { tol }}$

Equilibrium constants $K_{\text {unbr }}$, obtained for reaction 1 at temperatures of -10 , -20 and $-30^{\circ} \mathrm{C}$ (Tab. 1), yield values of $\Delta H_{\mathrm{unbr}}^{0}=-24 \pm 3 \mathrm{~kJ} / \mathrm{mol}$ and $\Delta S_{\mathrm{unbr}}^{0}=$ $-86 \pm 12 \mathrm{~J} /(\mathrm{mol} \cdot \mathrm{K})$.

The rates of formation of $\left(\mathrm{C}_{5} \mathrm{H}_{5}\right)_{2} \mathrm{Cr}(\mathrm{CO})_{2}$, involving half-lives in the range 10-1000 $\mathrm{min}$, are in accord with a first-order dependence on the concentrations of both $\left(\mathrm{C}_{5} \mathrm{H}_{5}\right)_{2} \mathrm{Cr}(\mathrm{CO})$ and dissolved $\mathrm{CO}$. They were reproduced with reasonable accuracy in repeated conversion reactions following intermittent regeneration of the monocarbonyl complex at reduced $\mathrm{CO}$ pressures. The temperature dependence of

* If these solutions are kept under elevated $\mathrm{CO}$ pressures at temperatures above $0^{\circ} \mathrm{C}$ for extended periods, however, there is a decay of these dicarbonyl bands and a rise of new IR absorptions at $1952,1924,1893$ and $1782 \mathrm{~cm}^{-1} ;\left(\mathrm{C}_{5} \mathrm{H}_{5}\right)_{2} \mathrm{Cr}_{2}(\mathrm{CO})_{6}$, for which $\nu(\mathrm{CO})$ bands at 1952,1929 and $1914 \mathrm{~cm}^{-1}$ were observed in cyclohexane solution [7], is the most likely product of this decay reaction.

** The presence of this species in these reaction systems is excluded by the reversibility of the spectral changes described above.

*** Derived from $P(\mathrm{CO})$ and centigrade temperature $\delta$ by the empirical relation $C(\mathrm{CO})=P(\mathrm{CO})$. $0.0071-P(\mathrm{CO})^{3} \cdot(2.2-\delta \cdot 0.09) \times 10^{-8}[2]$. 
Table 1

Complex formation constants, $K_{\text {unbr }}$ und $K_{\text {brdg }}{ }^{a}$ for equilibria 1 and 2, respectively, at various temperatures, $T$

\begin{tabular}{llllll}
\hline & $T\left({ }^{\circ} \mathrm{C}\right)$ & & & \\
& -10 & -20 & -30 & -40 & -47 \\
\hline$K_{\text {unbr }}\left(M^{-1}\right)$ & $1.9 \pm 0.3$ & $3.2 \pm 0.1$ & $4.7 \pm 0.5$ & & \\
$K_{\text {brdg }}\left(M^{-1}\right)$ & & $0.59 \pm 0.07$ & $0.74 \pm 0.08$ & $1.23 \pm 0.05$ & $1.9 \pm 0.1$ \\
\hline
\end{tabular}

a Determined from the equilibrium absorbance of the corresponding monocarbonyl complex, $A_{1900}^{\mathrm{E}}$, at a given $\mathrm{CO}$ concentration $\mathrm{C}(\mathrm{CO})$, as $K_{\mathrm{unbr} / \mathrm{brdg}}=\left(A_{1900}^{\mathrm{\theta}}-A_{1900}^{\mathrm{E}}\right) / A_{1900}^{\mathrm{E}} \cdot C(\mathrm{CO}), A_{1900}^{0}$ being the monocarbonyl absorbance at a $\mathrm{CO}$ pressure of 1 bar.

Table 2

Rate constants $k_{\exp }{ }^{a}, k_{2}{ }^{b}$ and $k_{\text {unbr }}{ }^{c}$ for the formation of $\left(\mathrm{C}_{5} \mathrm{H}_{5}\right)_{2} \mathrm{Cr}(\mathrm{CO})_{2}$ as a function of $\mathrm{CO}$ concentration, $\mathrm{C}(\mathrm{CO})$, and temperature, $T$

\begin{tabular}{|c|c|c|c|c|c|c|}
\hline $\begin{array}{l}T \\
\left({ }^{\circ} \mathrm{C}\right)\end{array}$ & $\begin{array}{l}P(\mathrm{CO}) \\
\text { (bar) }\end{array}$ & $\begin{array}{l}C(\mathrm{CO}) \\
(M)\end{array}$ & $\begin{array}{l}t_{1 / 2} \\
(\mathrm{~min})\end{array}$ & $\begin{array}{l}k_{\exp }\left(\times 10^{3}\right) \\
\left(\min ^{-1}\right)\end{array}$ & $\begin{array}{l}k_{2}\left(\times 10^{3}\right) \\
\left(M^{-1} \cdot \min ^{-1}\right)\end{array}$ & $\begin{array}{l}k_{\text {unbr }}\left(\times 10^{3}\right) \\
\left(M^{-1} \cdot \min ^{-1}\right)\end{array}$ \\
\hline \multirow[t]{4}{*}{-10} & 38 & 0.27 & 49 & 14 & 34 & \\
\hline & 75 & 0.52 & 39 & 18 & 23 & \\
\hline & 120 & 0.80 & 13 & 55 & 45 & \\
\hline & 150 & 0.96 & 15 & 45 & 31 & $33 \pm 6$ \\
\hline \multirow[t]{4}{*}{-20} & 38 & 0.27 & 147 & 4.7 & 13 & \\
\hline & 75 & 0.52 & 95 & 7.3 & 11 & \\
\hline & 120 & 0.78 & 48 & 14 & 14 & \\
\hline & 150 & 0.93 & 45 & 16 & 13 & $13 \pm 1$ \\
\hline \multirow[t]{4}{*}{-30} & 38 & 0.27 & 770 & 0.9 & 2.7 & \\
\hline & 75 & 0.51 & 277 & 2.5 & 4.0 & \\
\hline & 130 & 0.82 & 210 & 3.3 & 3.3 & \\
\hline & 150 & 0.90 & 193 & 3.6 & 3.3 & $3.3 \pm 0.3$ \\
\hline
\end{tabular}

abtained as slope $\cdot(-1)$ of $\ln \left(A_{1900}^{\mathrm{t}} / A_{1900}^{0}\right)$ against time $t .{ }^{b}$ Second-order rate constant $k_{2}=k_{\exp } /$ $\left(C(\mathrm{CO})+\left(K_{\text {unbr }}\right)^{-1}\right)$; from $k_{\text {exp }}=k_{\text {forw }}+k_{\text {backw }}=k_{2} \cdot C(\mathrm{CO})+k_{-2}=k_{2} \cdot C(\mathrm{CO})+k_{2} / K_{\text {unbr }}{ }^{c}$ Mean value of $k_{2}$ at any given temperature.

the mean second-order rate constant, $k_{\text {unbr }}$ (Tab. 2) ${ }^{*}$, yields an activation ethalpy $\Delta H^{\ddagger}=58 \pm 6 \mathrm{~kJ} / \mathrm{mol}$ and an activation entropy $\Delta S^{\ddagger}=-89 \pm 15 \mathrm{~J} /(\mathrm{mol} \cdot \mathrm{K})$ for the CO-induced ring-slippage reaction **.

Reaction of $\left(\mathrm{CH}_{3}\right)_{4} \mathrm{C}_{2}\left(\mathrm{C}_{5} \mathrm{H}_{4}\right)_{2} \mathrm{Cr}(\mathrm{CO})$ with an excess of $\mathrm{CO}$.

When tetramethylethanediyl-bridged chromocene complex $\left(\mathrm{CH}_{3}\right)_{4} \mathrm{C}_{2}\left(\mathrm{C}_{5} \mathrm{H}_{4}\right)_{2}$ $\mathrm{Cr}(\mathrm{CO})$ a thermally stable, sublimable compound [6], is exposed to elevated pressures of $\mathrm{CO}$ in toluene solution, there are spectral changes quite similar to those described above for the unbridged analogue. After appropriate reaction time (see

* Since these rate determinations involve approach to equilibrium, experimental pseudo-first-order rate constants $k_{\text {exp }}$ are the sum of $k_{\text {forw }}=k_{2} \cdot C(\mathrm{CO})$ and $k_{\text {backw }}=k_{-2}=k_{2} / K_{\text {unbr }}$ (see Tab. 2).

** Obtained as slope $\cdot(-1)$ and $y$-axis intercept of a plot, against $1 / T$, of $R \cdot \ln \left(k_{\text {unbr }} \cdot c^{0} \cdot h /\left(k_{\mathrm{B}} \cdot T\right)\right)$; with $R=8.314 \mathrm{~J} /(\mathrm{mol} \mathrm{K}), k_{\text {unbr }}$ in $l /(\mathrm{mol} \cdot \mathrm{s}), c^{0}=1 \mathrm{~mol} / \mathrm{l}, h=6.262 \times 10^{-34} \mathrm{~J} \cdot \mathrm{s}, k_{\mathrm{B}}=1.381 \times$ $10^{-23} \mathrm{~J} / \mathrm{K}$. 
below), there is again a decrease in the monocarbonyl band at $1900 \mathrm{~cm}^{-1}$ together with the rise of two $\nu(\mathrm{CO})$ bands at 1939 and $1875 \mathrm{~cm}^{-1}$. The close coincidence of these two bands (again of intensity ratio $I_{\text {sym }} / I_{\text {asym }} \approx 1.0$ ) with those observed for $\left(\eta^{3}-\mathrm{C}_{5} \mathrm{H}_{5}\right)\left(\eta^{5}-\mathrm{C}_{5} \mathrm{H}_{5}\right) \mathrm{Cr}(\mathrm{CO})_{2}$ leaves no reasonable doubt that there is an analogous ring-slipped dicarbonyl complex, $\left(\mathrm{CH}_{3}\right)_{4} \mathrm{C}_{2}\left(\eta^{3}-\mathrm{C}_{5} \mathrm{H}_{4}\right)\left(\eta^{5}-\mathrm{C}_{5} \mathrm{H}_{4}\right) \mathrm{Cr}(\mathrm{CO})_{2}$ under these conditions.

The pressure dependence of these reversible IR spectral changes is again in accord with the CO-dependent complex formation equilibrium 2. Formation con$\left(\mathrm{CH}_{3}\right)_{4} \mathrm{C}_{2}\left(\mathrm{C}_{5} \mathrm{H}_{4}\right)_{2} \mathrm{Cr}(\mathrm{CO})_{1 \mathrm{ol}}+\mathrm{CO}_{\mathrm{tol}} \rightleftharpoons\left(\mathrm{CH}_{3}\right)_{4} \mathrm{C}_{2}\left(\mathrm{C}_{5} \mathrm{H}_{4}\right)_{2} \mathrm{Cr}(\mathrm{CO})_{2 \mathrm{tol}}$

stants $K_{\text {brdg }}$ for the ring-bridged dicarbonyl complex (Tab. 1) are lower by a factor of 5-6 at -20 and $-30^{\circ} \mathrm{C}$ than those of $K_{\text {unbr }}$ for the unbridged reaction system, and result in values of $\Delta H_{\mathrm{brdg}}^{0}=-21 \pm 4 \mathrm{~kJ} / \mathrm{mol}$ and $\Delta S_{\mathrm{brdg}}^{0}=-89 \pm 18 \mathrm{~J} /(\mathrm{mol}$. $\mathrm{K})$. The accuracy of these data is not sufficient to reveal whether the relatively minor difference in free enthalpy associated with the presence of the interannular bridge, $\delta \Delta G_{\mathrm{brdg}}^{0}=+3.6 \pm 0.2 \mathrm{~kJ} / \mathrm{mol}$, is mainly due to an enthalpy or to an entropy effect.

A most remarkable difference between bridged and unbridged reaction systems, however, concerns the reaction kinetics. While the latter systems yielded reasonably reproducible reaction rates when a given sample was repeatedly converted into the dicarbonyl complex after intermittent regeneration of $\left(\mathrm{C}_{5} \mathrm{H}_{5}\right)_{2} \mathrm{Cr}(\mathrm{CO})$ by release of $\mathrm{CO}$ pressure, similar reaction cycles caused unusual rate changes for the analogous reaction 2. While a rather slow pseudo-first order reaction was observed for each initial reaction run of any given sample, rate increases by factors of 2-10 were observed for each subsequent reaction cycle, until, finally, the rate of reaction 2 became unmeasurably fast. Even under these conditions, however, the $\nu(\mathrm{CO})$ absorption bands were unchanged in respect of their frequencies and the $P(\mathrm{CO})$ dependence of their intensities.

In exploring the causes for these unusual kinetic observations, we found that the rate of reaction 2 is critically dependent on the presence of small amounts of some $\mathrm{Cr}^{\mathrm{III}}$ species: if, for example about 10 mol-percent of the ansa-chromocene carbonyl was oxidized to the $\mathrm{Cr}^{\text {III }}$ state by addition of 0.1 equivalent of allyl iodide [15], reaction 2 was accelerated by a factor of more than 10. When, on the other hand, formation of any $\mathrm{Cr}^{\text {lII }}$ species was suppressed by addition of 0.1 equivalent of $\mathrm{C}_{6}\left(\mathrm{CH}_{3}\right)_{6} \mathrm{Fe}\left(\mathrm{C}_{5} \mathrm{H}_{5}\right)$ [16] as a strong reductant, reaction 2 occurred slowly at $-30^{\circ} \mathrm{C}$ und 100 bar $\mathrm{CO}$, with a second-order rate constant $k_{\text {brdg }} 2.1 \times 10^{-3}$ $1 /(\mathrm{mol} \cdot \mathrm{min})$, which is roughly comparable to that for the unbridged reaction system under these conditions. In the presence of this reductant, repeated reaction runs, after regeneration of $\left(\mathrm{CH}_{3}\right)_{4} \mathrm{C}_{2}\left(\mathrm{C}_{5} \mathrm{H}_{4}\right)_{2} \mathrm{Cr}(\mathrm{CO})$, yielded reproducible rates, as previously observed for $\left(\mathrm{C}_{5} \mathrm{H}_{5}\right)_{2} \mathrm{Cr}(\mathrm{CO})$.

We must thus assume that the large acceleration observed for repeated runs without added reductant is due to the inadvertent introduction of small amounts of some $\mathrm{Cr}^{\text {III }}$ species, e.g., by a $\mathrm{CO}$-induced disproportionation of $\left(\mathrm{CH}_{3}\right)_{4} \mathrm{C}_{2}\left(\mathrm{C}_{5} \mathrm{H}_{4}\right)_{2^{-}}$ $\mathrm{Cr}^{\mathrm{II}}(\mathrm{CO})$ to $\left(\mathrm{CH}_{3}\right)_{4} \mathrm{C}_{2}\left(\mathrm{C}_{5} \mathrm{H}_{4}\right)_{2} \mathrm{Cr}^{\mathrm{III}}(\mathrm{CO})^{+}$and $\left(\left(\mathrm{RC}_{5} \mathrm{H}_{4}\right) \mathrm{Cr}^{1}(\mathrm{CO})_{3}\right)_{2}$, with $\mathrm{R}=$ $\left(\mathrm{CH}_{3}\right)_{4} \mathrm{C}_{2}\left(\mathrm{C}_{5} \mathrm{H}_{4}^{-}\right)$or $\left(\mathrm{CH}_{3}\right)_{4} \mathrm{C}_{2}\left(\mathrm{C}_{5} \mathrm{H}_{4}^{-}\right)$, analogous to that observed with unbridged chromocene under elevated $\mathrm{CO}$ pressure at room temperature.

From studies on the electrochemistry of $\left(\mathrm{CH}_{3}\right)_{4} \mathrm{C}_{2}\left(\mathrm{C}_{5} \mathrm{H}_{4}\right)_{2} \mathrm{Cr}(\mathrm{CO})$ [1] it is clear that this species is easily and reversible oxidized, at potentials of ca. $-0.4 \mathrm{~V}$ vs. 

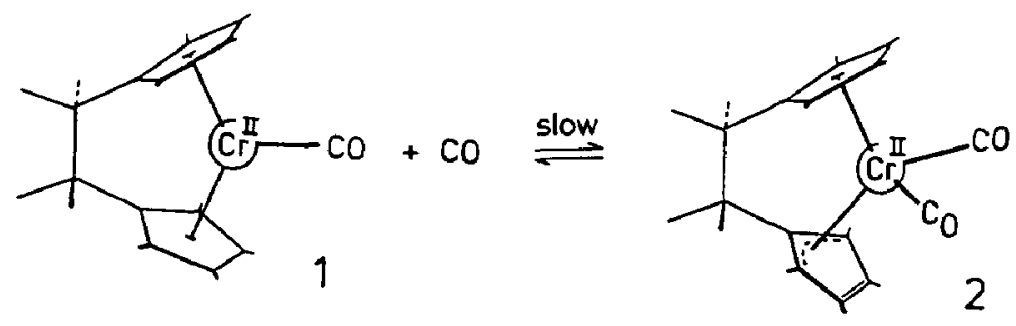

$$
2+\sqrt{2} 2
$$

$$
1+\sqrt{1}
$$

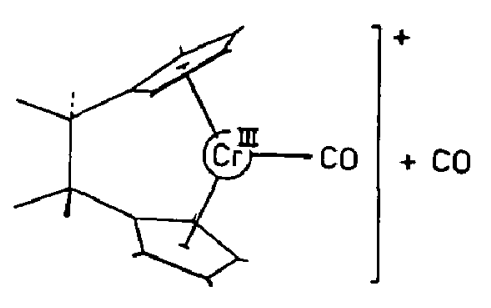

Scheme 1

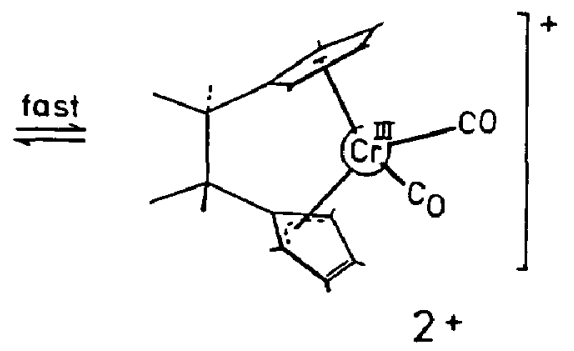

SCE, to a monocation, which is stable towards loss of CO on the CV time scale. It thus appears that this 17 -electron species reacts much faster with excess $\mathrm{CO}$ than the neutral monocarbonyl to form a cation $\left(\mathrm{CH}_{3}\right)_{4} \mathrm{C}_{2}\left(\mathrm{C}_{5} \mathrm{H}_{4}\right)_{2} \mathrm{Cr}(\mathrm{CO})_{2}^{+}$* While we did not observe this species directly in our $\mathrm{CV}$ studies at ambient $\mathrm{CO}$ pressure, it can be assumed that it is more easily reducible, owing to its two $\pi$-acceptor $\mathrm{CO}$ ligands, than the monocarbonyl cation. Electron transfer from the monocarbonyl starting material to any $\left(\mathrm{CH}_{3}\right)_{4} \mathrm{C}_{2}\left(\mathrm{C}_{5} \mathrm{H}_{4}\right)_{2} \mathrm{Cr}(\mathrm{CO})_{2}^{+}$formed * will thus generate both neutral dicarbonyl product and the reactive $\left(\mathrm{CH}_{3}\right)_{4} \mathrm{C}_{2}\left(\mathrm{C}_{5} \mathrm{H}_{4}\right)_{2} \mathrm{Cr}(\mathrm{CO})^{+}$cation, setting up the catalytic cycle represented in Scheme 1.

After observing these redox effects on the rate of reaction 2 , we reinvestigated the unbridged reaction system for similar redox effects, but the rate of reaction 1 proved to be insensitive to the addition of small amounts (ca. 0.1 equivalent) of allyl iodide as an oxidant or of $\mathrm{C}_{6}\left(\mathrm{CH}_{3}\right)_{6} \mathrm{Fe}\left(\mathrm{C}_{5} \mathrm{H}_{5}\right)$ as a reductant.

Apparently, formation of the dicarbonyl cation $\left(\mathrm{C}_{5} \mathrm{H}_{5}\right)_{2} \mathrm{Cr}(\mathrm{CO})_{2}^{+}$in any amount sufficient to set up a catalytic cycle similar to that described in. Scheme 1 is prevented, even at elevated $\mathrm{CO}$ pressures, by the thermodynamic and kinetic

* Direct IR observation of this reaction was impossible owing to the low solubility of the monocarbonyl cation in toluene.

** The higher reduction potential of the dicarbonyl than of the monocarbonyl cation implies a smaller formation constant for the dicarbonyl cation than for the neutral dicarbonyl complex (i.e. than $\left.\boldsymbol{K}_{\text {brdg }}\right)$. Small amounts of the dicarbonyl cation could be sufficient, however, to set up a redox-catalysed reaction cycle. 

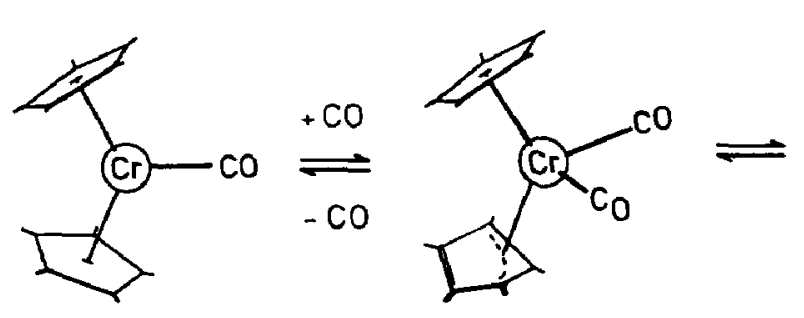

endo

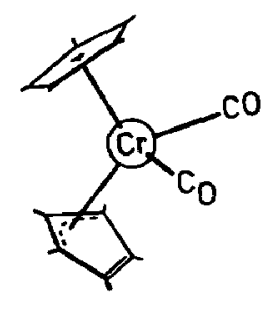

exo
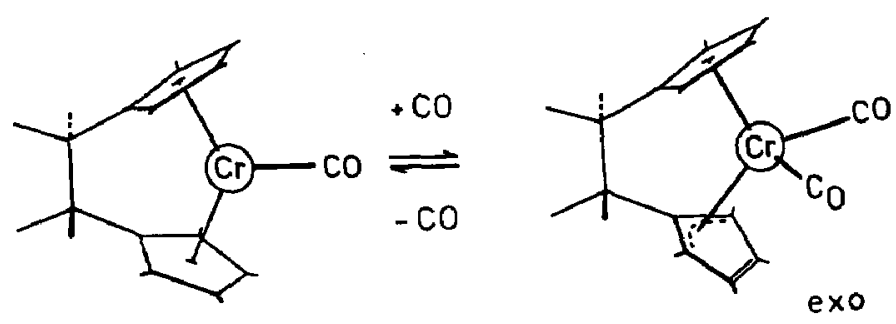

Scheme 2

instability of the unbridged monocarbonyl cation $\left(\mathrm{C}_{5} \mathrm{H}_{5}\right)_{2} \mathrm{Cr}(\mathrm{CO})^{+}$, which rapidly loses its $\mathrm{CO}$ ligand [1], in contrast to its tetramethylethanediyl-bridged counterpart $\left(\mathrm{CH}_{3}\right)_{4} \mathrm{C}_{2}\left(\mathrm{C}_{5} \mathrm{H}_{4}\right)_{2} \mathrm{Cr}(\mathrm{CO})^{+}$, which is quite stable on the $\mathrm{CV}$ time scale.

\section{Conclusions}

The surprisingly small amount of energy by which the formation of the dicarbonyl complex is thermodynamically less favourable for the bridged as compared with the unbridged chromocene derivative, shows that the transformation to an $\eta^{3}$-cyclopentadienyl coordination geometry is only minimally hindered by the presence of an inter-annular bridge. The tungsten congener $\left(\eta^{3}-\mathrm{C}_{5} \mathrm{H}_{5}\right)\left(\eta^{5}-\mathrm{C}_{5} \mathrm{H}_{5}\right) \mathrm{W}(\mathrm{CO})_{2}$ was found (at least in the crystalline state) to adopt an endo conformation, i.e. with the "open" side of its $\eta^{3}$-coordinated ring oriented away from the $\mathrm{CO}$ ligands [5]. While $\left(\eta^{3}-\mathrm{C}_{5} \mathrm{H}_{5}\right)\left(\eta^{5}-\mathrm{C}_{5} \mathrm{H}_{5}\right) \mathrm{Cr}(\mathrm{CO})_{2}$ could adopt either conformation, only an exo conformation, involving an orientation of the "open" side of the $\eta^{3}$-bound ring section toward the $\mathrm{CO}$ ligands, would be compatible with the presence of the interannular bridge in $\left(\mathrm{CH}_{3}\right)_{4} \mathrm{C}_{2}\left(\eta^{3}-\mathrm{C}_{5} \mathrm{H}_{4}\right)\left(\eta^{5}-\mathrm{C}_{5} \mathrm{H}_{4}\right) \mathrm{Cr}(\mathrm{CO})_{2}$ (cf. Scheme 2). Small energy differences reported for exo and endo conformers of related $\eta^{3}$-allyl $\eta^{5}$ cyclopentadienyl molybdenum dicarbonyl (and cationic carbonyl nitrosyl) complexes [17], would be in line with the small value of $\delta \Delta G_{\mathrm{brdg}}^{0}=+3.6 \mathrm{~kJ} / \mathrm{mol}$ observed above.

The kinetics of these CO-uptake reactions demonstrate that the occasionally-invoked generation of an open coordination site in a coordinatively saturated sandwich or half-sandwich compound by $\eta^{5} \rightarrow \eta^{3}$ ring-slippage is a kinetically non-trivial 
process, with an activation energy of the order of ca. $60 \mathrm{~kJ} / \mathrm{mol}{ }^{*}$. The observation that the activation entropy for the CO-induced ring-slippage, $\Delta S_{\mathrm{unbr}}^{\ddagger} \approx-89 \mathrm{~J} /(\mathrm{mol}$ $\cdot \mathbf{K}$ ), is practically equal to the standard entropy change for the overall CO-uptake reaction, $\Delta S_{\mathrm{unbr}}^{0} \approx-86 \mathrm{~J} /(\mathrm{mol} \cdot \mathrm{K})$, excludes an initial $\eta^{5} \rightarrow \eta^{3}$-conversion of one ring ligand in $\left(\mathrm{C}_{5} \mathrm{H}_{5}\right)_{2} \mathrm{Cr}(\mathrm{CO})$ as the rate-determining step of the overall reaction. The similarity between $\Delta S_{\mathrm{unbr}}^{\ddagger}$ and $\Delta S_{\mathrm{unbr}}^{0}$ strongly indicates an associative mechanism, i.e. a transition state in which the entering $\mathrm{CO}$ ligand is an essential part. Whether the coordination geometry of the 'slipping' $\mathrm{C}_{5} \mathrm{H}_{5}$ ligand in this transition state is closer to the initial $\eta^{5}$ - or to the final $\eta^{3}$-arrangement cannot be decided from our data.

The electron-transfer catalysis observed for the CO-induced $\eta^{5} \rightarrow \eta^{3}$ ring slippage of the tetramethylethanediyl-bridged chromocene system is, in principle, just another example of a redox-catalysed ligand exchange reaction. While we did not further investigate the kinetic details of this process, there is ample precedent for the assumption * that a 17-electron species such as $\left(\mathrm{CH}_{3}\right)_{4} \mathrm{C}_{2}\left(\mathrm{C}_{5} \mathrm{H}_{4}\right)_{2} \mathrm{Cr}(\mathrm{CO})^{+}$can undergo an associative process, i.e. that the release of a $\pi$-electron pair of one of the ring ligands is preceeded by the uptake of the second $\mathrm{CO}$ ligand, or possibly even by that of the 18th electron in the final reduction step. While facile ring-slippage reactions in odd-electron complexes have been reported recently ${ }^{* *}$, we still find it surprising that the rate of an apparently trivial reaction such as 2 should be so critically dependent on the availability of an electron-transfer reaction path.

\section{Experimental}

Chromocene, $\left(\mathrm{C}_{5} \mathrm{H}_{5}\right)_{2} \mathrm{Cr}$ [20], and $\left(\mathrm{CH}_{3}\right)_{4} \mathrm{C}_{2}\left(\mathrm{C}_{5} \mathrm{H}_{4}\right)_{2} \mathrm{Cr}(\mathrm{CO})$ [6] were prepared by published procedures and stored and handled with exclusion of air, either in a glove-box or in a vacuum-line. IR measurements on toluene solutions of these compounds and their CO-induced reactions were performed in an IR cell with internal circulation, suitable for isothermic and isobaric measurements under elevated gas pressures, and evaluated as previously described [2].

\section{Acknowledgements}

We thank Dr. $\mathrm{H}$. Schwemlein for help with the preparation of $\left(\mathrm{CH}_{3}\right)_{4} \mathrm{C}_{2}\left(\mathrm{C}_{5} \mathrm{H}_{4}\right)_{2}-$ $\mathrm{Cr}(\mathrm{CO})$ and Professor D. Astruc, University of Bordeaux, for helpful comments and for a gift of $\left(\mathrm{C}_{6}\left(\mathrm{CH}_{3}\right)_{6}\right) \mathrm{Fe}\left(\mathrm{C}_{5} \mathrm{H}_{5}\right)$. Financial support of this work by Deutsche Forschungsgemeinschaft (grant Bri 510), by Fonds der Chemischen Industrie and by funds of the University of Konstanz is gratefully acknowledged.

\section{References}

1 E.U. van Raaij, S. Mönkeberg, H. Kiesele and H.H. Brintzinger, J. Organomet. Chem., 356 (1988) 307.

* For the second-order reaction of $\left(\mathrm{C}_{5} \mathrm{H}_{5}\right) \mathrm{Co}(\mathrm{CO})_{2}$ with ${ }^{13} \mathrm{CO}$, in which the species $\left(\eta^{3}-\mathrm{C}_{5} \mathrm{H}_{5}\right) \mathrm{Co}(\mathrm{CO})_{3}$ was suggested to represent the crucial intermediate, Basolo and coworkers [18] reported similar activation parameters of $\Delta H^{\ddagger} \approx 60 \mathrm{~kJ} / \mathrm{mol}$ and $\Delta S^{\ddagger} \approx-100 \mathrm{~J} /(\mathrm{mol} \cdot \mathrm{K})$.

** See e.g. ref. 19 and references therein. 
2 E.U. van Raaij, C.D. Schmulbach and H.H. Brintzinger, J. Organomet. Chem., 329 (1987) 275.

3 J.M. O'Connor and C.P. Casey, Chem. Revs., 87 (1987) 307.

4 K.L.T. Wong and H.H. Brintzinger, J. Am. Chem. Soc., 97 (1975) 5143; Dissertation K.L.T. Wong, University of Michigan, 1974.

5 G. Huttner, H.H. Brintzinger, L.G. Bell, P. Friedrich, V. Bejenke and D. Neugebauer, J. Organomet. Chem., 145 (1978) 329.

6 H. Schwemlein, L. Zsolnai, G. Huttner and H.H. Brintzinger, J. Organomet. Chem., 256 (1983) 285; Dissertation H. Schwemlein, Universität Konstanz, 1985.

7 E.O. Fischer, W. Hafner and H.O. Stahl, Z. Anorg. Allg. Chem., 282 (1955) 47.

8 E.O. Fischer and K. Ulm, Z. Naturforsch. B, 15 (1960) 59; Chem. Ber., 94 (1961) 2413.

9 W.C. Mills, III. and M.S. Wrighton, J. Amer. Chem. Soc., 101 (1979) 5830.

10 J.W. Lauher and R. Hoffmann, J. Am. Chem. Soc., 98 (1976) 1729.

11 F.A. Cotton and G. Wilkinson, Adv. Inorg. Chem., 4th edit. New York, 1980, p. 1073.

12 J.L. Atwood, K.E. Stone, H.G. Alt, D.C. Hrncir and M.D. Rausch, J. Organomet. Chem., 132 (1977) 367.

13 J.L. Atwood, R.D. Rogers, W.E. Hunter, C. Floriani, G. Fachinetti and A. Chiesi-Villa, Inorg. Chem., 19 (1980) 3812.

14 D.J. Sikora, M.D. Rausch, R.D. Rogers and J.L. Atwood, J. Am. Chem. Soc., 103 (1981) 1265.

15 E.O. Fischer and K. Ulm, Chem. Ber., 95 (1962) 692.

16 J.R. Hamon, D. Astruc and P. Michaud, J. Am. Chem. Soc., 103 (1981) 758; D. Astruc, Acc. Chem. Res., 19 (1986) 377.

17 J.W. Faller, C.C. Chen, M.J. Mattina and A. Jakubowski, J. Organomet. Chem., 52 (1973) 361; J.W. Faller and A.M. Rosan, J. Am. Chem. Soc., 98 (1976) 3388; B.E.R. Schilling, R. Hoffmann and J.W. Faller, ibid., 101 (1979) 592.

18 M.E. Rerek and F. Basolo, Organometallics, 2 (1983) 372; J. Am. Chem. Soc., 106 (1984) 5908.

19 R.M. Kowaleski, A.L. Rheingold, W.C. Trogler and F. Basolo, J. Am. Chem. Soc., 108 (1986) 2460; R.M. Kowaleski, F. Basolo, W.C. Trogler, R.W. Gedridge, T.D. Newbound and R.D. Ernst, ibid., 109 (1987) 4860.

20 J.J. Eisch and R.B. King, Organometallic Synthesis, Vol. 1, New York, 1965, p. 67. 